\title{
EFFECT OF THE ANTI-TRUST LAW ON GENERAL BUSINESS
}

\author{
By Alexander D. Noyes, \\ Financial Editor, "Evening Post," New York.
}

The best apology for adding anything further, to the very comprehensive discussions of the anti-trust law which have already been made this afternoon, lies in the fact that no speaker yet has devoted himself to the subject of the afternoon. That subject assigned for discussion is, "The effect of the Sherman law on general business," and it is that aspect of the Sherman act which I shall briefly discuss. There is a familiar story of a puzzled citizen who asked his well-posted friend, "What is this Sherman Act that everybody is talking about?" and who received in answer a scornful look and the inquiry whether he had never heard any one sing "Marching through Georgia." The story might be dismissed as a mere extravagance of American humor, but for the fact that an almost equally extraordinary idea seems to pervade many minds, even in the walks of high finance, as to what. the Sherman Act really is and really does.

An eminent lawyer, in a formal brief in court, declared a few days ago that "the losses inflicted by this act on business have been as great as those inflicted by the Civil War." It is an interesting fact that this statement was made in the very week when talk of revival of business confidence, in the face of an unchanged policy of courts and executives in the matter of the trusts, had become the conspicuous incident of the day throughout the trade circles of the country. It was made in a week when the minor companies formed out of the Standard Oil, as a result of last year's disintegration under order of the court, were increasing their dividends, and when the market valuation of these component parts of the old Standard Oil Trust exceeded, when taken as a whole, the highest price ever reached by the stock of the old holding company in the palmiest days of its history.

Mr. Talbert has taken no such extreme ground as this. In most respects, his discussion of the anti-trust law is eminently fair. 
Yet I cannot help feeling that a little of this strange misconception surrounds even his very interesting analysis. Mr. Talbert says that strict enforcement of the anti-trust law is impracticable. Well, we might agree upon that conclusion if we could first agree on the definitions. But what is strict enforcement? That is the whole nub of the question.

Does he mean such literal construction as Mr. Justice Lacombe suggested in his famous circuit court opinion of November, 1908, in the Tobacco Trust case, when he said that two individuals, each running an express wagon across a state frontier, who should form a partnership with one another, would at once be amenable to prohibitive clauses of the law? If the business community ever took that dictum seriously, the time for trade prosperity to be demoralized was in the immediate sequel to that particular opinion. Yet that circuit court obiter dictum was immediately followed by a year of general business revival in this country and of extravagant speculation for the rise on the stock exchange.

But however that may be, it must be evident that the Supreme Court, by its decisions of last spring on the Oil and Tobacco cases, has effectively put an end to any such interpretation of the law. The prescribing of the "rule of reason" by the Chief Justice, in behalf of a virtually unanimous court, means the fixing of the rule of common sense as the guide to interpretation of the law, and the rejection of the nonsensical imaginary interpretations which interested people have pretended to draw. From the day the law was enacted, there has never been the slightest doubt that such application of it was the purpose of its authors. There was, it is true, an outcry last May against the Supreme Court's "emasculating" of the law and against its "reading another meaning" into the statute by prescribing this rule of reason in interpretation. But that, I think, was effectively silenced when the author of the law of 1890 , the venerable ex-Senator Edmunds, raised his voice from his place of retirement to say of the senate judiciary committee which drew up that law-a committee in which such other eminent constitutional lawyers as Evarts and Hoar had an important place:

"The judiciary committee believed that the well known principles guiding the courts in the application and construction of statutes would lead them to give the words of the act a beneficial and remedial, rather than an injurious and technical tone hurtful 
to any honest trade. . . . The fear that some literal construction of the words 'restraint of trade' might lead to sacrifice of some just, fair and wholesome business arrangements may be safely dismissed, for, if the principle and purpose of the constitution and act have any foundation at all there can be no such restraint, because such conduct is not restraining but is promotive of and beneficial to the public interest."

To which Senator Edmunds, in a subsequent interview, added the declaration that "a statute that should undertake to define its own terms would at once necessarily involve a definition of its own definitions, and so on. It needs no lawyer to tell intelligent men how absurd and impracticable such legislation would be."

My main criticism of Mr. Talbert's interesting paper, therefore, would affect his remarks on what will follow disruption of Big Business by the anti-trust law. He nowhere points out the probability of such disruption, or an instance where such disruption has occurred, except in the case of combinations so big as to exercise virtual or potential monopoly in their respective trades. So far is the law from declaring a given business illegal solely on the ground of bigness, that we have authority, from the circuit court opinion to the Supreme Court decision in the Oil and Tobacco cases, and from the Attorney-General to the President of the United States, for denying any such scope or purpose to the law. It was denied with the utmost explicitness by the circuit court in its ruling on the recent Tobacco Trust dissolution plan, when it rejected the insistent demand of the independent tobacco interests for breaking into minute fragments the corporate structure of the old Tobacco Trust. And to this consideration President Taft has added the following words, in a message to Congress on the subject, marked by his usual judicial attitude:

"Those critics who speak of this disintegration in the trust as a mere change of garments have not given consideration to the inevitable working of the decree, and understand little the personal danger of attempting to evade or set at naught the solemn injunction of a court whose object is made plain by the decree and whose inhibitions are set forth with a detail and comprehensiveness unexampled in the history of equity jurisprudence."

Therefore, Mr. Talbert's argument as to the dangerous bearing of the law on such interests as our foreign trade and our home manu- 
acturing economies is not at all fairly in point, unless he proves that advantages in those fields are not attainable save by the largest combinations ever yet conceived, and under monopolistic or semimonopolistic conditions. Indeed, a highly interesting question has lately arisen as to whether, at some point, the very bigness of a given trade combination may not deprive the enterprise of these precise advantages. The question has come into the field of practical controversy, through the recent discussion of the cause for broken rails and subsequent railway disasters. In this controversy it has been publicly alleged by eminent railway men, among them Mr. James J. Hill, that the quality of rails laid down to-day under present conditions has deteriorated as compared with what they were a dozen years ago; that rails turned out by the Steel Corporation are inferior in quality and durability to rails purchased from the Krupps more than a dozen years ago; and that rails manufactured now by different plants in one combination will not maintain a uniform standard of quality. This evidence is perhaps not conclusive on the general question, but it is at least suggestive to those who know what happens when a manufacturing plant or combination begins to lack supervision of the whole enterprise from the head, along with pressure from the central committee to maintain dividends on inflated capital. Both of these evils will inevitably arise when the trust passes a certain stage of magnitude. The most wasteful system of manufacture would be that of complete monopoly; this belief is indeed the fundamental argument of the opponents of state socialism. Yet most of Mr. Talbert's arguments as to the efficiency of the trust would, if left unqualified, equally defend monopoly. If bigness, merely as bigness, ensures success in foreign trade and in home economies, and if these benefits cannot be secured except from the biggest present combinations, then why stop short of the biggest conceivable combination, which is monopoly?

I have only one or two considerations to add to what I have already briefly set forth. Mr. Talbert says that "certain fundamental laws of trade called the trusts into existence in the first place, and made them important and necessary factors in trade." I am aware that he refers to the destructive competition of the later eighties and the business demoralization which ensued. But is he quite sure of his history, so far as concerns the great combinations which are really in question? Were the trusts of 1899 
and 1901, with their prodigious combination of existing plants and with their subsequent combination of the new combinations, called into existence by such fundamental laws as we are asked to assume, or were they the outcome of a stock promotion mania and an amalgamation craze, such as the world never saw before or since, and probably never will see again? Even in the matter of foreign trade we must ask when it was that the so-called "American invasion" of the foreign consuming world, through export of American manufactures, occurred. The record will show that it was in 189? and 1898 that the outcry arose in Europe for the European manufacturing world to "stand together to resist the trans-oceanic peril." But trusts such as the steel and copper combinations, as they now exist, were only formed in 1899 and 1901 . The "American invasion" was conducted by corporations such as those into which application of the anti-trust law would dissolve the existing enormous trusts. Moreover, export of the products of these and other industries actually decreased when the trusts were formed, a few years later, and its subsequent increase was in a smaller ratio than in the years immediately before the trusts were organized.

In concluding, I wish to express my entire concurrence with Mr. Talbert's opinion that we never can return to the "days of small individual business." But I am personally quite as much convinced that we shall never again return to days such as those in which counsel of the Northern Securities admitted, before the Supreme Court, that the system on which that combination was formed might lead to the lodging of all the railroads in the United States in the hands of a few individuals. Neither do I believe that we shall ever seriously revert to the recently familiar argument of serious men, that competition, with its incalculably beneficial results of past generations on industrial energy, invention and progress, must hereafter be dismissed offhand as a factor in modern civilization. 